\title{
Is Russia successful in attracting foreign direct investment? Evidence based on gravity model estimation
}

\author{
Oleg Mariev, Igor Drapkin, Kristina Chukavina ${ }^{1}$
}

\begin{abstract}
The aim of this paper is twofold. First, it is to answer the question of whether Russia is successful in attracting foreign direct investment (FDI). Second, it is to identify partner countries that "overinvest" and "underinvest" in the Russian economy. We do this by calculating potential FDI inflows to Russia and comparing them with actual values. This research is associated with the empirical estimation of factors explaining FDI flows between countries. The methodological foundation used for the research is the gravity model of foreign direct investment. In discussing the pros and cons of different econometric methods of the estimation gravity equation, we conclude that the Poisson pseudo maximum likelihood method with instrumental variables (IV PPML) is one of the best options in our case. Using a database covering about $70 \%$ of FDI flows for the period of 2001-2011, we discover the following factors that explain the variance of bilateral FDI flows in the world economy: GDP value of investing country, GDP value of recipient country, distance between countries, remoteness of investor country, remoteness of recipient country, level of institutions development in host country, wage level in host country, membership of two countries in a regional economic union, common official language, common border and colonial relationships between countries in the past. The potential values of FDI inflows are calculated using coefficients of regressors from the econometric model. We discover that the Russian economy performs very well in attracting FDI: the actual FDI inflows exceed potential values by 1.72 times. Large developed countries (France, Germany, UK, Italy) overinvest in the Russian economy, while smaller and less developed countries (Czech Republic, Belarus, Denmark, Ukraine) underinvest in Russia. Countries of Southeast Asia (China, South Korea, Japan) also underinvest in the Russian economy.
\end{abstract}

Key words: determinants of FDI, gravity model of FDI, Poisson Pseudo Maximum Likelihood method, potential values of FDI

JEL Classification: F21

Received: 24 June 2015/Accepted: 30August 2016/ Sent for Publication: 16 September 2016

\footnotetext{
${ }^{1}$ Ural Federal University, Graduate School of Economics and Management, Mira Ave 19, Yekaterinburg, Russia. E-mail: olegmariev@mail.ru, i.m.drapkin@urfu.ru, ch.chris@mail.ru.
} 


\section{Introduction}

Foreign direct investment plays a very important role in the global economy. Over the past 3 decades, FDI flows increased by 26.3 times while the world GDP increased only by 5.8 times (UNCTAD 2011). In 2013, the value of global FDI flows was $\$ 1.45$ bln that comprises $7.7 \%$ of international trade of goods and $2 \%$ of global GDP (UNCTAD 2014).

Countries compete for foreign direct investment in the modern economy. This is due to the positive impact FDI has on the recipient economy. In addition to direct effects (increase in GDP value, increase in budget revenues, decrease in unemployment, etc.), FDI also positively influences the host economy indirectly: through knowledge and technology diffusion, an increase in demand for local intermediate goods, investment in training of personnel, etc.

FDI flows are more concentrated than the production of goods and services in the world economy (see Table 1). The share of the 27 major FDI recipients (countries that attracted more than $\$ 100$ bln during 2001-2011) comprises $80 \%$ of total FDI flows, while the share of these countries in the world GDP is only $74.7 \%$ for the same period. Furthermore, the share of the 23 major FDI donors (countries that invested more than $\$ 100$ bln for 2001-2011) constitutes 91\% of total FDI flows, while their share in the world GDP is only $77.4 \%$.

If we compare the share of countries in world GDP with their share in world FDI inflows and outflows, we'll see mixed results (see Table 2). USA, Italy and Japan have a larger share in world GDP than in world FDI inflows and outflows. Canada and UK hold a larger share in world FDI flows than in world GDP. France and Germany invest a relatively high amount abroad and attract relatively small FDI. Countries that offer special tax regimes for holding companies (Netherlands, Belgium, Luxemburg, Switzerland) and new industrial states (Malaysia, Singapore) hold a significant share of world FDI flows. Of course, offshore countries have a larger share in world FDI flows than in world GDP.

The situation described above tells us that the distribution of FDI flows in the world economy is not only proportional to the economic size of the countries, but is probably influenced by a set of other factors. The identification of these factors is an important scientific task.

In this paper, we construct an econometric model explaining bilateral FDI flows in the modern economy. Using this model we calculate potential FDI inflows for major recipient countries and compare them with actual values.

After solving the problem of finding the correct econometric model and calculating potential FDI flows, we consider the case of a specific country. We calculate potential bilateral FDI inflows for the Russian Federation and compare them with actual values. 
Table 1 Share of major FDI recipients and donors in total FDI flows and GDP, cumulative for $2001-2011$

\begin{tabular}{|c|c|c|c|c|}
\hline Countries & FDI, \$bln & $\begin{array}{l}\text { Share in } \\
\text { world } \\
\text { FDI } \\
\text { flows, \% }\end{array}$ & $\begin{array}{c}\text { GDP, } \\
\text { \$bln }\end{array}$ & $\begin{array}{c}\text { Share } \\
\text { in } \\
\text { world } \\
\text { GDP, } \\
\%\end{array}$ \\
\hline All countries (237) & 12680.6 & 100.0 & $\begin{array}{r}565 \\
694.0\end{array}$ & 100.0 \\
\hline $\begin{array}{l}\text { Countries that attracted over } \$ 50 \text { bln. for } \\
\text { the period ( } 44 \text { countries) }\end{array}$ & 11303.0 & 89.1 & $\begin{array}{r}508 \\
647.0\end{array}$ & 89.9 \\
\hline $\begin{array}{l}\text { Countries that attracted over } \$ 100 \mathrm{bln} \text {. } \\
\text { for the period ( } 27 \text { countries })\end{array}$ & 10148.3 & 80.0 & $\begin{array}{r}422 \\
322.0\end{array}$ & 74.7 \\
\hline $\begin{array}{l}\text { Countries that invested over } \$ 50 \mathrm{bln} \text {. for } \\
\text { the period ( } 33 \text { countries) }\end{array}$ & 12416.0 & 96.1 & $\begin{array}{r}480 \\
204.8\end{array}$ & 84.9 \\
\hline $\begin{array}{l}\text { Countries that invested over } \$ 100 \text { bln. } \\
\text { for the period ( } 23 \text { countries) }\end{array}$ & 11755.3 & 91.0 & $\begin{array}{r}437 \\
656.0\end{array}$ & 77.4 \\
\hline
\end{tabular}

Source: calculated by the authors using unctadstat.unctad.org and data.worldbank.org

We choose the Russian Federation as the object of our research for the following reasons. First, Russia is the largest FDI recipient among post-communist economies. Second, Russia is the only post-communist economy that not only attracts large amounts of FDI, but is also one of the major FDI investors in the world. And third, there has been little research of the factors affecting FDI inflows to the Russian economy to date.

The analysis of descriptive statistics doesn't offer an answer to the question of whether Russia succeeded in attracting foreign direct investment. On the one hand, Russia is one of the few developing countries in the world whose share in the world FDI inflows $(2.75 \%)$ and outflows (2.64\%) exceeds its share in the world GDP (1.95\%). On the other hand, the indicator of FDI flows per capita for Russia is quite modest when compared with developed countries (see Table 2).

In this paper, our contribution to the issue of bilateral FDI flows is as follows. First, we complement the results of previous research by identifying determinants of bilateral FDI flows in the world economy. For this purpose, we use a database that covers about $70 \%$ of world FDI flows for the period of 2001-2011 and apply IV PPML for econometric estimation. Next, we calculate potential values of the FDI inflows for major recipient economies on the basis of the econometric model and compare them with actual values. We discover that actual FDI inflows in the Russian economy exceed potential values by 1.72 times. Finally, we compare the actual and potential values of FDI inflows to Russia from its main investing partners and identify that large developed countries overinvest in the Russian economy, while smaller and less developed countries underinvest in Russia. 
Table 2 Countries' share in the world GDP, FDI inflows and FDI outflows (cumulative for 2001-2011)

\begin{tabular}{|c|c|c|c|c|c|c|}
\hline Country & $\begin{array}{c}\text { FDI } \\
\text { inflows, } \\
\text { \$bln. }\end{array}$ & $\begin{array}{c}\text { Share } \\
\text { in } \\
\text { world } \\
\text { GDP, } \\
\%\end{array}$ & $\begin{array}{c}\text { Share in } \\
\text { world } \\
\text { FDI } \\
\text { inflows, } \\
\%\end{array}$ & $\begin{array}{c}\text { Share in } \\
\text { world FDI } \\
\text { outflows, } \\
\%\end{array}$ & $\begin{array}{c}\text { GDP } \\
\text { per } \\
\text { capita, } \\
\$\end{array}$ & $\begin{array}{c}\text { FDI } \\
\text { inflows } \\
\text { per } \\
\text { capita, \$ }\end{array}$ \\
\hline Australia & 279.6 & 1.53 & 2.20 & 0.80 & 37936 & 1225 \\
\hline Belgium & 481.7 & 0.79 & 3.80 & 2.61 & 38198 & 4114 \\
\hline Brazil & 322.0 & 2.45 & 2.54 & 0.53 & 6634 & 154 \\
\hline Canada & 412.0 & 2.41 & 3.25 & 3.66 & 37952 & 1146 \\
\hline China & 884.4 & 6.73 & 10.88 & 7.23 & 2621 & 95 \\
\hline France & 278.7 & 4.45 & 2.20 & 5.24 & 35961 & 398 \\
\hline Germany & 450.5 & 5.83 & 3.55 & 6.10 & 36947 & 505 \\
\hline Denmark & 37.1 & 0.53 & 0.29 & 0.64 & 50217 & 618 \\
\hline India & 220.9 & 2.04 & 1.74 & 0.83 & 901 & 17 \\
\hline Italy & 233.9 & 3.67 & 1.84 & 3.08 & 32172 & 362 \\
\hline Japan & 81.8 & 9.13 & 0.65 & 5.16 & 37013 & 59 \\
\hline Korea & 103.4 & 1.74 & 0.82 & 1.21 & 18636 & 196 \\
\hline Luxembourg & 103.6 & 0.08 & 0.82 & 1.29 & 86923 & 19923 \\
\hline Malaysia & 59.4 & 0.34 & 0.47 & 0.60 & 6570 & 206 \\
\hline Mexico & 271.9 & 1.78 & 2.14 & 0.54 & 8167 & 221 \\
\hline Netherlands & 356.6 & 1.39 & 2.81 & 4.70 & 43622 & 1981 \\
\hline Russia & 348.2 & 1.95 & 2.75 & 2.64 & 6976 & 220 \\
\hline Singapore & 306.5 & 0.31 & 2.42 & 1.48 & 34398 & 6043 \\
\hline Spain & 393.9 & 2.35 & 3.11 & 4.68 & 27246 & 809 \\
\hline Switzerland & 208.9 & 0.89 & 1.65 & 3.50 & 60337 & 2517 \\
\hline UK & 935.7 & 4.51 & 7.38 & 8.62 & 37941 & 1392 \\
\hline USA & 1858.6 & 25.89 & 14.66 & 20.03 & 43960 & 558 \\
\hline
\end{tabular}

Source: calculated by the authors using unctadstat.unctad.org and data.worldbank.org

\section{Literature review}

Currently, there is no specific microeconomic model of FDI. All the FDI models are developed based on international trade models, where FDI presents capital migration between countries.

The classical theory (Ricardo theory) and neoclassical theory (Heckscher - Ohlin Samuelson theory) of international trade are based on the absolute mobility of capital wherefrom the price of capital equalizes due to international trade (factor price equalization theorem). This means that FDI flows in the economy are relatively insignificant and could not be taken into account while analyzing the international trade of goods. Mundell (1957) considers FDI from the viewpoint of neoclassical theory as a result of barriers implementation in the process of goods trade. According to the Mundell model, trade costs (tariffs and export tax) are the important factor influencing investment movement between countries. 
In the mid ' 80 s, new trade models appeared. They implied imperfect competition in the markets, increasing returns to scale and product differentiation. In these models, FDI is an alternative to international trade, therefore transport costs are a very important factor influencing a firm's decision of whether to make an investment outside the country.

Exploring the factors influencing FDI flows from the viewpoint of new trade theories, authors extract factors of vertical FDI (associated with cost saving) and horizontal FDI (associated with market search).

Vertical FDI is considered in the papers of Helpman (1984) and Helpman and Krugman (1985). In such models, the main determinant of FDI in the world economy is the difference in factor prices. This type of FDI occurs between countries with different production factor endowment and between countries on different levels of economic development (developed and developing countries).

Horizontal FDI is considered based on Markusen models $(1984,2002)$ and the model of Markusen and Venables (1998). In these models, the key factor of FDI is the market size of host and investing countries. The other important factors are: economies of scale (both at firm and plant level) and the level of product differentiation in the industry.

The main disadvantage of the models considered above is the assumption of firms' homogeneity. It is known that in reality, only the most effective firms in the industry invest abroad. The new findings in this field are linked to the analysis of Melitz-type models with differences in firms' productivity.

Helpman, Melitz and Yeaple (2004) considered a firm's choice between export of goods and horizontal FDI and came to the conclusion that only the most productive firms operate in foreign markets. In addition, among the firms operating in foreign markets, the less productive ones choose export of goods and the more productive ones create FDI. Therefore, the authors show that the productivity of a firm has great impact on the decision of the firm to invest abroad. As the models with heterogeneous firms are constructed on the basis of monopolistic competition models, the important factors of FDI are transportation costs, market size of the countries and product differentiation level in the industry. Grossman, Helpman and Szeidl (2006) show that the level of a firm's productivity also influences the decision of the firm to create vertical FDI.

In classical models, the main factor influencing the firms' decision to invest abroad was transportation costs. In modern theories, the significance of factors such as market size, production factor prices, and product differentiation of goods in the branch has been proven. Finally, in the "new new theories," one more factor of FDI was extracted - the level of the investing firm's productivity.

The models reviewed in this part of the article may be used for the identification of variables that explain the structure and dynamics of world FDI flows within gravity models.

Tinbergen (1962), who studied international trade flows, originally suggested applying the gravity model to economic processes. Brainard (1997) first applied the gravity model to FDI. Generally, it could be written as follows:

$$
F_{i j}=\frac{M_{i} M_{j}}{D_{i j}},
$$


where $F_{i j}$ is the FDI flow from country $j$ to country $i, M_{i}$ and $M_{j}$ are the indicators representing the sizes of countries $i$ and $j$ (often their GDP), $D_{i j}$ is the distance between the countries.

Aside from distance and country size, there are many other factors that could have an impact on the FDI flow value. They can be separated into several groups. The first group is is associated with economic factors: openness of country importing FDI (Kristjansdottir, 2004; Talamo, 2003), inflation rate (Liebrecht and Riedl, 2012), government expenditures level (Azeem, Hussain and Hussain, 2012), labor costs (Liebrecht and Riedl, 2012), external trade level (Cevis and Camurdan, 2007), taxes (Folfas, 2011) etc. The second group represents institutional factors: political stability level (Sova et al, 2009), corruption level (Kayam and Hisarciklilar, 2009), and R\&D level in the country (Bormann, Jungnickel and Keller, 2005), investors' protection level (Pagano and Volpin, 2004). The third group deals with indicators that characterize the similarity between two countries: common language (Folfas, 2011), common border (Africano, 2005), and common historical features (Africano, 2005).

At the present time, the number of research papers devoted to the estimation of the FDI determinants in the Russian economy is limited. For the empirical estimation of FDI determinants of a single country that takes regional FDI flows into consideration, most of the studies discussed below use a region-level database for FDI flows in Russia.

Most of the research papers find evidence for the gravity model's hypothesis. The size of Russian regions is significant in Brock (1998), Broadman and Recanatini (2001), Iwasaki and Suganuma (2005), Manaenkov (2000). The distance between the investor country and host region negatively affects FDI flows based on the studies of Ledyaeva and Linden (2006) and Buccellato and Santangelo (2009). Manaenkov (2000) and Castiglione et al (2012) do not find a significant negative influence of distance on regional FDI flows.

In relation to the Russian economy, the following factors that significantly affect FDI inflows (additional to gravity determinants) were identified: level of infrastructure development (Broadman and Recanatini, 2001; Iwasaki and Suganuma, 2005), location of a port in the region (Castiglione et al, 2012; Ledyaeva, 2007), trade openness (Yukhanaev et al, 2014), resource endowment (Iwasaki and Suganuma, 2005; Ledyaeva and Linden, 2006), crime level (Brock, 1998), social development level (Castiglione et al, 2012), agglomeration factors (Iwasaki and Suganuma, 2005; Ledyaeva and Linden, 2006; Ledyaeva 2007).

Some researchers consider the crisis of 1998 as the turning point for the level of FDI inflows in Russia. Broadman and Recanatini (2001) suggest the existence of a postcrisis downshift in FDI, while Iwasaki and Suganuma (2005) reject this.

\section{Methodology}

Let us turn to the estimation of FDI flows. The usual way to estimate using the gravity model is to take logarithms. However, for this reason there are some technical difficulties that stem from the specificity of FDI structure: FDI data contains a large amount of zeros and negative values. The problem is that taking logarithms means not 
including these observations, because the logarithmic function is not defined for zero and negative values. Moreover, logarithmic specifications are very often heteroskedastic. It is impossible and unreasonable to include absolutely all factors that could influence FDI flows in a regression equation, we therefore face the problem of unobserved heterogeneity, that means that there are unaccounted correlations between observed and unobserved variables. The way to tackle the endogeneity problem is discussed further in the next section.

Kristjansdottir (2004) suggests an interesting approach to solving the problem of taking logarithms of zero and negative values. In order not to exclude variables and reduce the sample, the author suggests applying the inverse hyperbolic sine function for the dependent variable in place of the logarithm function. The inverse hyperbolic sine function is very similar to the natural logarithm function but is also defined for the entire real axis. Another way to save observations in the sample with a value of zero is to define the dependent variable as $\ln (1+F D I)$ [a similar approach is used for trade flows by Wang and Winters, 1991, as well as by Baldwin and Di Nino, 2006].

The methods of econometric estimation that could be applied to gravity models can be separated into two groups: linear and non-linear methods.

The most trivial is the OLS method. It is applied to a linear regression derived by taking logarithms of the gravity equation. Estimation results are usually biased and inconsistent due to data loss, heteroskedasticity and unobserved heterogeneity (Silva and Tenreyro, 2006). In spite of the fact that this method is not the most effective for the gravity model estimation, it is used in many research papers (e.g. Africano, 2005; Ledyaeva and Linden, 2006).

For the gravity models estimation, cross-sectional and panel data could be used. The usage of cross-sectional data decreases the effectiveness of the model because it is assumed in this case that FDI flows don't change over time (Mátyás, 1998). If this assumption doesn't hold, the estimation results will be biased. The other estimation approach is panel data estimation that allows taking specific country effects into account. Panel data with fixed effects (FE) and random effects (RE) are used to identify and test time and country specific features.

The need to use the panel FE method is indicated by inconsistent results of the OLS model estimation. Cheng and Wall (2005) claimed that inclusion of fixed effects in the gravity model allows control for heterogenic trade relations. In particular, Cheng and Wall use the panel fixed effect approach to eliminate heterogeneity bias present in other linear methods. Some researchers (Folfas, 2011; Egger and Pffafermayr, 2004) point out the disadvantages of using standard panel FE methods (distance, a fundamental variable in the gravity model, is time invariant) and RE methods (individual effects could correlate with some explanatory variables). Authors suggest using the Hausman Taylor approach as a solution to this problem.

Among the non-linear methods, the most widely used are the non-linear OLS method, Feasible Generalized Least Squares, the Heckman two-step procedure, the Gamma Pseudo Maximal Likelihood Method, and the Poisson pseudo maximal likelihood method (PPML). The specificity of these methods is the use of a constant-elasticity model instead of a model utilizing logarithms. 
Econometric analysis of the gravity model widely uses the PPML method, which was originally applied to trade flows by Silva and Tenreyro (2006). This method solves the main problems that appeared in gravity model testing (the presence of zeros and heteroskedasticity), provides unbiased and consistent estimators and is one of the bestchoice methods. Silva and Tenreyro showed that in the presence of heteroskedasticity, the estimation of log-linearized form changes the properties of error term, which becomes correlated with explanatory variables in the presence of heteroskedasticity.

The PPML method was applied to FDI flows in several papers. Kleinert and Toubal (2010) use PPML to estimate several specifications of the gravity equation, which were derived from the theoretical models. Another author who used PPML method in his research was Paniagua (2011). He compares this method with OLS and the so called HMR method (Helpman, Melitz and Rubenstein, 2008). The author comes to the conclusion that compared to the HMR method, PPML is more sensitive to zero flows. Moreover, the results of estimation by means of HMR are very similar to the results derived by the OLS method. PPML results differ from the OLS results. Another disadvantage of the HMR method is the elimination of variables in pursuit of identification. Paniagua concludes that the use of PPML is more reasonable than the use of HMR: results are rather intuitive and correspond with theoretical assumptions.

All the methods used in econometric research have different advantages and shortcomings (see Appendix 1). The selection of the optimal method should be based on the specific features of the data being studied and the problems that can be solved by means of gravity models.

\section{Methods and results of econometric analysis}

The dependent variable in our research is the value of FDI flow from country $j$ to country $i$ in year $t\left(f d i_{i j t}\right)$.

Our choice of the explaining variables is made on an ad hoc basis (due to the condition that there is an absence of an acknowledged theoretical model of FDI), is consistent with the present array of the empirical research and reflects the influence of factors considered in the literature review. We choose the following explanatory variables: GDP of countries $i$ and $j$, distance between countries, remoteness of FDI importer and exporter relative to third-party countries, common language, common border, wage level in the host economy, level of economic freedom in the host country, participation in regional economic unions and colonial relationships between countries in the past.

The hypotheses regarding the impact of explanatory variables on the dependent variable are as follows.

- FDI flow positively correlates with the size of the host economy ( gdpimp $_{i t}$, taken as the GDP of the recipient country in year $t$ ), because the size of the market attracts foreign investors into the country. In larger markets, foreign companies gain higher profits not only because of the larger value of sales, but also because of the opportunity to decrease their average costs due to increasing returns to scale.

- FDI flow positively correlates with the size of the investing economy ( dpexp $_{j t}$, taken as the GDP of the exporting country in year $t$ ), because in larger countries, 
there is a higher number of firms that are able to invest abroad. In addition, due to the increasing returns to scale, companies from larger countries are usually more effective when compared to companies from smaller countries.

- The values of FDI between countries are negatively dependent on the distance between countries (dist $i_{i}$, taken as the distance between the capitals of two countries) for two reasons. Firstly, the increase in distance leads to an increase in transportation costs (MNCs often ship knowledge-intensive intermediate goods to their plants abroad). Secondly, an increase in distance usually means an increase in differences between countries that make investment more risky.

- The next factor significant to the FDI level is the indicator of remoteness of the two countries involved in the investment process in regard to other countries.

The use of a proxy for remoteness is borrowed from the literature on the estimation of the gravity model for trade flows (Wei, 1996; Silva and Tenreyro, 2006). In trade, the idea is that a country that is more isolated from the world will trade more, all else equal, since there will be less competition for companies selling in its market. The analogy to FDI would be that isolated markets have fewer competitors and will therefore be perceived as a better place to invest, holding all else equal (Bobonis and Shatz, 2007).

We calculate the proxy for the remoteness of the FDI recipient and for the remoteness of the investor country.

The proxy for the remoteness of the FDI recipient $i$ (remotehost $t_{i}$ ) is the sum of relative distances from the exporter to all other countries. The smaller this value is, the closer countries are to the exporter and, respectively, the more remote the FDI recipient is. We expect positive dependence between the variable remotehost $t_{i}$ and FDI flows: the smaller the value of remotehost ${ }_{i}$ (the FDI recipient becomes more remote), the smaller the FDI flows (there are no incentives for the home country to invest because there are a lot of countries around).

We calculate the proxy for remoteness of FDI recipient $i$ as follows:

$$
\text { remotehost }_{i}=\sum_{j, j \neq i} \frac{\text { dist }_{i j}}{G D P_{j} / G D P_{W}},
$$

where $G D P_{j}$ is GDP of country $j, G D P_{W}$ is the total GDP of all the rest of the countries. ${ }^{2}$

The proxy for the remoteness of the FDI home country $\mathrm{j}$ (remotehome r $_{j}$ ) is the sum of relative distances from the importer to all other countries. The smaller this value is, the more countries are around the importer and, respectively, the more remote the investor country is. We expect negative dependence between the variable remotehome $e_{j}$ and FDI flows: the smaller the value of remotehome ${ }_{j}$ (the investor country becomes more remote), the higher the FDI flows (there is "nowhere" else to invest because there are no countries around).

\footnotetext{
${ }^{2}$ Alternative approaches to calculating remoteness exist. For example, Coe et al (2002) calculated remoteness of country $i$ for all $j$ not equal to $i$. Battersby and Ewing (2005) construct the remoteness variable by creating a sum of the multiplications of each partner country's GDP and distance and then dividing it by world GDP. We do not see crucial differences in alternative methods in calculating the remoteness variable.
} 
We calculate the proxy for remoteness for investor country $j$ as follows:

$$
\text { remotehome }_{j}=\sum_{i, i \neq j} \frac{\text { dist }_{i j}}{G D P_{i} / G D P_{W}} .
$$

- The wage level in the host country of FDI ( wage $_{i t}$ ) should have an impact on the FDI flows into the country, but the character of this impact is somewhat unclear. On the one hand, higher wages increase the purchasing power of a population and should stimulate FDI flow into the country. On the other hand, higher wages mean higher costs for companies and could have a negative impact on FDI flows.

- The quality of institutions in the host economy is an important factor in FDI inflows. Effective institutions decrease the costs of running a business in the host economy. We measure the effectiveness of the institutions in the country using the index of economic freedom $\left(\right.$ ecfreed $_{i t}$ ) that is annually computed by the Heritage Foundation. The index of economic freedom is based on 10 factors grouped into four broad categories of economic freedom: rule of law (property rights, freedom from corruption); limited government (fiscal freedom, government spending); regulatory efficiency (business freedom, labor freedom, monetary freedom); and open markets (trade freedom, investment freedom, financial freedom). We expect the countries with a higher value of this index to attract more FDI ceteris paribus.

- A common border (dummy variable border $_{i j}$ ) between countries increases bilateral FDI due to the high similarity (social, cultural, economic) of bordering countries.

- A common national language (dummy variable comlang $_{i j}$ ) has positive impact on FDI flows between countries. The presence of a common language lowers communication costs, makes it easier to close business deals, and implies a mental and cultural similarity between the countries.

- The participation of countries in regional economic unions (dummy variable $r e u_{i j}$ ) stimulates investment activity between the member countries. As a rule, regional economic unions (REUs) aim to eliminate administrative and trade barriers between countries. This makes doing business inside REUs easier and allows FDI flows to grow. We expect a positive correlation between variable $r e u_{i j}$ and FDI flows.

- Colonial relationships between countries in the past (dummy variable comcol $_{i j}$ ) should stimulate bilateral investment flows due to the following reasons. Firstly, close economic cooperation between a parent state and its colony often continues after the fall of the colonial regime. Secondly, migration and financial flows between parent states and colonies are more tightly knit than those between other countries. Thirdly, parent states often preserve their influence on the colony even after a colonial regime is eliminated.

FDI flows data was mainly collected from the OECD website and also from the websites of national central banks ${ }^{3}$. The constructed database contains data for 112

\footnotetext{
${ }^{3}$ FDI data provided by international organizations and national government authorities suffers from serious drawbacks. This is mainly due to the fact that they are based on firm residency, while an acquiring company may not be an ultimate owner and/or a target company may not be an ultimate beneficiary target company (see Fujita (2005) for a detailed discussion). This creates a 
investing countries and 44 recipient countries for the period 2001-2011. The list of host countries comprises all OECD countries and other major recipients of FDI in the world economy. The list of investing countries includes all countries with nonzero FDI outflows during the 2001-2011 period. The list of investing and recipient countries is located in Appendix 2. The dependent variable is the value of investment flow from investing country (fixed sample of 112 countries) to host country (44 countries overall). The entire database consists of $53710(112 * 44 * 11$ minus $44 * 11$ diagonal observations minus 14 missing) observations. There is about $62 \%$ zero observations and $11 \%$ negative observations in the dataset. The constructed dataset covers about $70 \%$ of the world FDI flows for the considered period. The difference in the number of countries on the inflow side and on the outflow side in the dataset is due to the amount of data available to the authors.

Data on GDP was taken from the World Bank website (http://www.worldbank.org), distance variables were sourced from the website http://www.distancefromto.net/, the index of economic freedom was taken from the Heritage Foundation website (http://www.heritage.org/index/), remoteness terms and dummy variables were borrowed from the database constructed by Silva and Tenreyro.

Using the explaining variables listed above results in the following equation:

$$
\begin{aligned}
& f d i_{i j t}=
\end{aligned}
$$

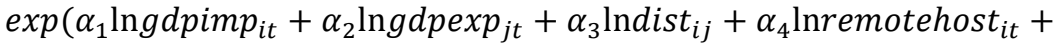

$$
\begin{aligned}
& \alpha_{5} \ln \text { remotehome }_{j t}+\alpha_{6} \ln \text { wage }_{i t}+\alpha_{7} \operatorname{lnecfreed} \text { fit }+\alpha_{8} \text { border }_{i j}+ \\
& \left.\alpha_{9} \operatorname{comlang}_{i j}+\alpha_{10} \operatorname{reu}_{i j}+\alpha_{11} \operatorname{comcol}_{i j}\right)+\varepsilon_{i j t} \text {; }
\end{aligned}
$$

We now move on to the estimation procedures and results. We use different estimation methods to make sure that the results are generally stable.

According to the standard procedure of panel data estimation, we should consider pooled OLS, panel data with random effects, and panel data with fixed effects. Based on the results of an F-test and Breusch-Pagan test we find that there are fixed and random effects in the data. Using the Hausman test we conclude that it is more reasonable to use the panel data estimation with fixed effects.

Taking a logarithm of a dependent variable leads to a loss of more than $70 \%$ of the observations in our dataset. In order to save null observations we also use $\ln (1+f d i)$ as the dependent variable, which "only" strips our database of the $11 \%$ comprised of negative observations. The results of panel RE and panel FE estimation with dependent variable $\ln (f d i)$ and $\ln (1+f d i)$ are presented in Table 3.

As it was stated in the previous chapter, least squares methods are not optimal for gravity model estimation. Firstly, the large number of observations is lost. Secondly, using panel RE is not consistent due to the Hausman test. Finally, using the panel FE method doesn't allow us to estimate time invariant regressors (distance and dummy variables). However, the results of the panel data estimation show that major elements

bias in any results from a large FDI panel. The reader should take data limitations into account when interpreting the results of this research. 
of the gravity model elicit expected signs: countries' GDP positively affects FDI flows, while distance affects them negatively.

We move on to the estimation of non-linear models next. The results of tobit and PPML estimation are presented in relevant columns of Table 4. In Stata, estimation of negative flows using the standard command poisson is not possible (this is caused by a limitation imposed by Stata in the glm command that is used inside PPML) even though the theoretical assumptions of this method don't pose such restrictions. In order not to eliminate negative values from the sample, we use PPML with instrumental variables (IV PPML), where all the regressors appear as instruments that allow maintaining all the values of the flows. As a result, with all regressors used as instruments, IV PPML is equivalent to the PPML method that works with negative observations. The code for IV PPML was designed by Silva and Tenreyro. Results of the estimation of the model by IV PPML are presented in the right column of Table 4.

When institutional variables are incorporated into the model, the problem of endogeneity needs to be dealt with. In our case, the problem of simultaneity would exist: FDI is likely to increase the quality of institutions in the recipient countries, while the quality of the institutions is in itself a factor attracting FDI [Ali et al, 2010; Francois and Manchin, 2013]. It should be noted here that PPML is a GMM interpretation of the ML method, whereas the GMM estimator is typically used to correct for bias caused by endogenous explanatory variables. PPML with instrumental variables estimates the parameters of a Poisson regression model in which some of the regressors are endogenous. The model is also known as an exponential conditional mean model in which some of the regressors are endogenous.

Almost all explaining variables are significant in the estimated equation. In addition to the expected impact of GDP and distance on FDI flows, we also observe that the variables for remoteness of importer and exporter, as well as the level of development of institutions in the recipient country, have expected signs. Dummy variables for common language, participation in the same regional economic union, and colonial relations in the past positively affect bilateral FDI flows.

The wage level in the recipient economy negatively affects FDI inflows. This result corresponds with the idea that higher wages incur higher costs for investment projects.

Opposing our hypothesis, a common border negatively affects bilateral FDI. In our opinion, this result may occur due to ongoing or past territorial conflicts between bordering countries, which act as a restraining factor for economic cooperation. Common border also had an ambiguous effect on bilateral FDI in Paniagua (2011).

We should emphasize that the influence of variables "wage" and "common border" on FDI flows is to be interpreted with caution as the sign before these variables changes when different estimation methods are used. 


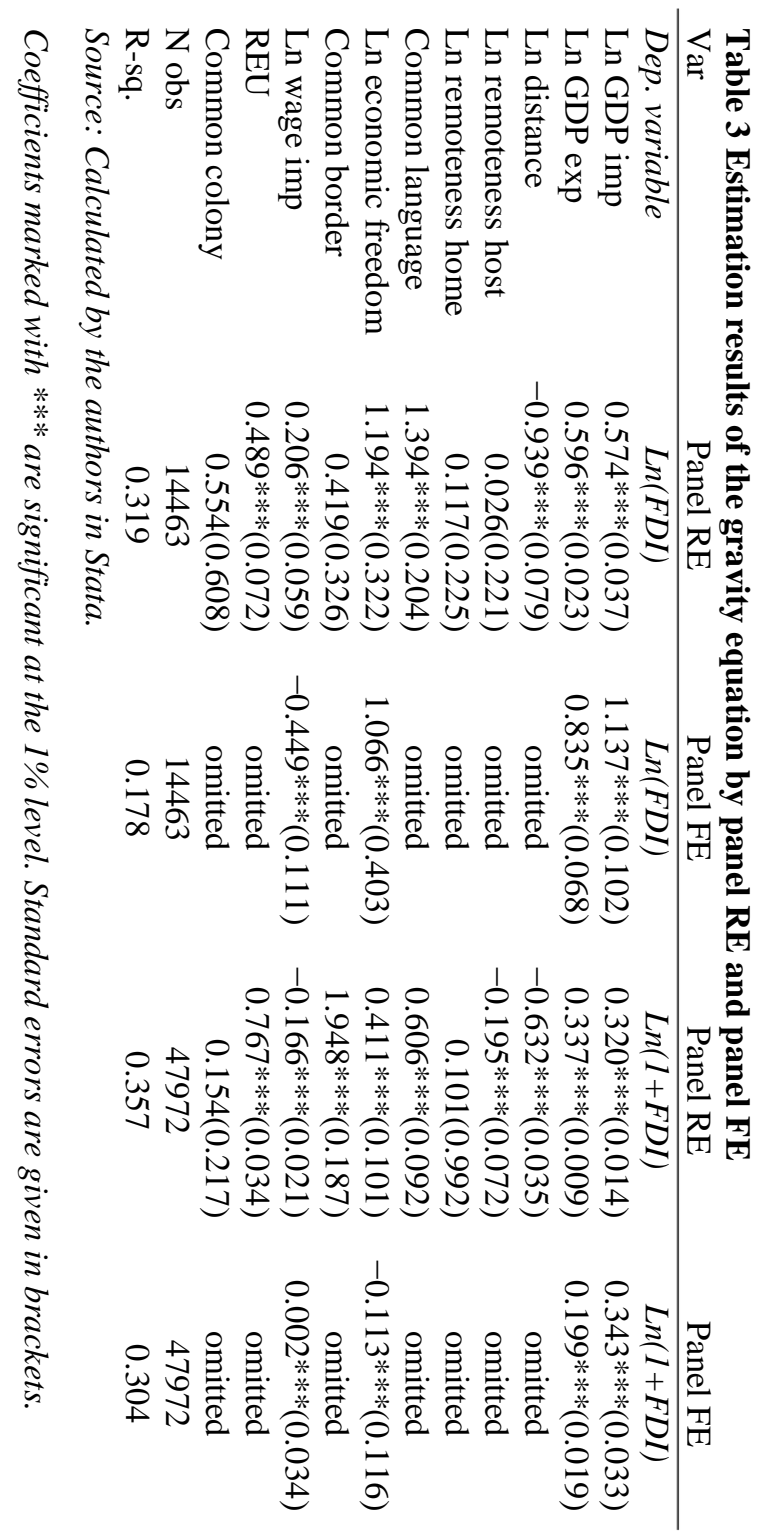




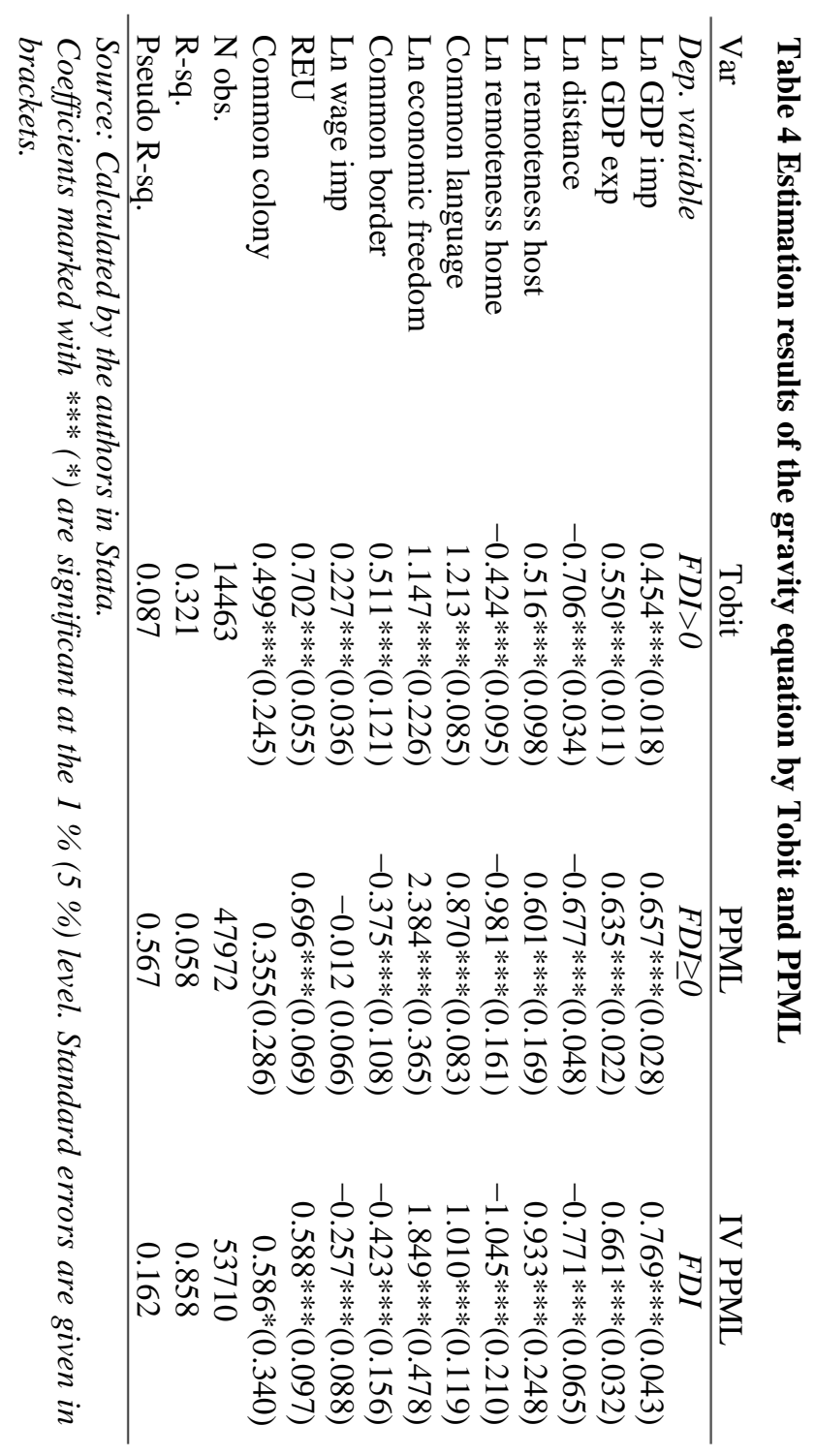




\section{Calculating FDI potentials}

The idea of calculating potential values based on the gravity model originates from trade flow studies. There are two approaches used to calculate trade potentials. Using the "out-of-sample" approach, calculation of trade potentials is based on the estimation of the dataset with the group of countries that are the most integrated into the world economy and operate at the frontier of trade efficiency. The difference between the observed and the predicted trade flows was interpreted as un-exhausted trade potential. Using the "in-sample" approach, all countries are included in the dataset. The residual of the estimated equation was interpreted as the difference between potential and actual bilateral trade relations (Egger, 2002, p. 297-298).

In his seminal paper, Egger discusses the pros and cons of the two above-mentioned approaches. He argues that in-sample estimations of trade potential are incorrect because large deviations of residuals in the gravity equation based on this method are not evidence of large deviations of trade from its potential, but rather an indicator of model misspecification. At the same time, Egger states that the out-of-sample approach may be only be suitable for countries in the early stages of development.

As Russia is not yet as integrated into the world economy as EU or Southeast Asian countries, for example, we can expect a considerable gap between potential and actual values of FDI. Following Egger (2002) and Shepotylo (2009), we use the out-of-sample approach.

Using the coefficients of the explanatory variables in the regression derived after an estimation using IV PPML, we calculate aggregated potential values of FDI inflows in Russia as well as potential values for main partner countries.

Calculated potential values of FDI inflows were compared to real values of FDI inflows. In the left part of Table 5, we list countries whose actual FDI inflows are higher than their potential values. In the right part, we list the countries with actual FDI lower than potential values.

The obtained results don't allow us to identify any tendencies among one group of countries or the other. There are developed countries in both the group with a higher potential than actual values of FDI (Austria, Germany, Italy, Japan) and in the group with a lower potential than actual values (Belgium, UK, Norway, France). We can say the same about post-communist countries: the actual value of FDI inflows is higher than its potential in Poland and Bulgaria; in Czech Republic, Hungary, and Lithuania, it is lower than its potential.

Along with Belgium, Iceland, Brazil and Indonesia, Russia is in the group of countries where actual values of FDI are higher than their potential. The actual values of FDI inflows in Russia during the considered period exceed potential values by 1.72 times.

At the first glance, this result seems surprising, but we have an explanation for it. Firstly, one should remember that Russia was extremely underinvested in the 90s (only \$18.6bln. of FDI inflows during the period 1990-1999, compared to \$293bln. during 2000-2010). After macroeconomic and political stabilization came following the crisis in 1998 and the economy began to grow fast, the Russian market became very attractive for foreign investors because of low competition and fast growth. We think that the 
extremely high (compared to the predictions of our model) value of FDI inflows in Russia in the first decade of the 21st century is a form of "compensation" for the extremely low FDI inflows in the last decade of the 20th century.

Table 5 Actual-to-potential ratios of FDI inflows

Actual FDI higher than potential

Actual FDI lower than potential

\begin{tabular}{lclc}
\hline Country & Ratio & Country & Ratio \\
\hline Iceland & 4.09 & Hungary & 0.72 \\
Belgium & 4.04 & Denmark & 0.68 \\
Brazil & 3.75 & Italy & 0.66 \\
Indonesia & 2.14 & Austria & 0.64 \\
Bulgaria & 2.07 & S. Korea & 0.63 \\
Sweden & 1.77 & Czech Republic & 0.62 \\
Russia & 1.72 & Cyprus & 0.61 \\
France & 1.64 & Germany & 0.58 \\
Spain & 1.54 & Lithuania & 0.57 \\
Poland & 1.50 & Greece & 0.41 \\
Switzerland & 1.40 & New Zealand & 0.37 \\
Ireland & 1.37 & Albania & 0.35 \\
Norway & 1.29 & Slovenia & 0.28 \\
Finland & 1.27 & Argentine & 0.26 \\
UK & 1.19 & Japan & 0.19 \\
\hline
\end{tabular}

Source: calculated by the authors.

The other possible explanation for high FDI inflows in the Russian economy is that Russia was very "popular" during the considered period: let us recall the 2007 decision to hold the Winter Olympic Games in Sochi, the 2010 decision to hold the FIFA World Cup in Russia, the 2009 USA - Russia attempt to "restart" relations, etc. Russia exerted ambitions as a global player in the international arena, and the most developed countries were quite benevolent to cooperation.

In the next step of our research, we calculate potential values of FDI inflows for major investors in the Russian economy and compare them with actual values. The results are presented in Table 6, where the countries with actual values higher than potential values are presented on the left, and the countries with actual values lower than potential values are presented on the right.

The major countries that "overinvest" in the Russian economy are Austria, the Netherlands, Sweden and Finland. The countries that "underinvest" most of all in the Russian economy are Denmark, Greece, Japan and Ukraine. Countries of Southeast Asia (China, South Korea, Japan) also underinvest in the Russian economy.

In the case of FDI inflows in the Russian economy, we can outline the following tendency: the FDI inflows from the largest and most developed countries exceed their potential values, while FDI flows from smaller and less developed countries are below their potential value. The investment flows from former USSR members, as well as from former communist countries, are below their potential value. 
Table 6 Actual-to-potential ratios of FDI inflows for the Russian economy

\begin{tabular}{lclc}
\multicolumn{2}{c}{ Actual FDI higher than potential } & \multicolumn{2}{c}{ Actual FDI lower than potential } \\
\hline Country & Ratio & Country & Ratio \\
\hline Austria & 8.84 & S. Korea & 0.56 \\
Netherlands & 5.67 & Spain & 0.54 \\
Sweden & 4.67 & Kazakhstan & 0.50 \\
Finland & 4.44 & Belarus & 0.48 \\
Switzerland & 4.19 & Bulgaria & 0.36 \\
France & 3.46 & Czech Republic & 0.30 \\
Germany & 3.00 & China & 0.28 \\
Belgium & 2.54 & Malaysia & 0.28 \\
UK & 2.45 & Denmark & 0.26 \\
Estonia & 1.55 & Greece & 0.15 \\
Latvia & 1.49 & Japan & 0.15 \\
Italy & 1.19 & Ukraine & 0.14 \\
\hline Source: calcan
\end{tabular}

Source: calculated by the authors.

\section{Conclusion}

This research is devoted to the investigation of actual and potential FDI inflows in the Russian economy. The basis of the empirical analysis is the gravity approach applied to the estimation of factors influencing FDI flows.

For empirical analysis we use a database with 53710 observations on 44 host countries and 112 investing countries during the period of 2001-2011.

Discussing the advantages and shortcomings of different econometric methods of the estimation gravity equation, we come to the conclusion that the Poisson pseudo maximum likelihood method with instrumental variables is one of the best-choice options in our case.

In our model, the variables that explain FDI flows in the world economy are as follows: GDP of home and host country, distance between countries, remoteness of investor and recipient country from other countries, level of institution development and wage level in the recipient country, participation of partner countries in the same regional economic union, common border, common official language and common colony in the past.

After defining the appropriate model explaining the flows of FDI in the economy, we calculate the potential values of FDI outflows and inflows in Russia and its main partner countries.

These potential values were compared with the real values, and we discover that the Russian economy performs very well in attracting FDI: the actual FDI inflows exceed potential values by 1.62 times. Large developed countries (France, Germany, UK, Italy) overinvest in the Russian economy, while smaller and less developed countries (Czech Republic, Belarus, Denmark, Ukraine) underinvest in Russia. Countries of Southeast Asia (China, South Korea, Japan) also underinvest in the Russian economy. 
Acknowledgement: For helpful comments and suggestions, we thank two anonymous referees.

Funding: This research was supported by the Russian Scientific Fund grant No. 15-1810014 "Projection of optimal socio-economic systems in turbulence of external and internal environment".

Disclosure statement: No potential conflict of interest was reported by the authors.

\section{References}

ALI, F. A., N. FIESS, R. MACDONALD. (2010). Do Institutions Matter for Foreign Direct Investment? Open Economies Review, Volume 21, Issue 2, pp. 201219.

AFRICANO, A. (2005). FDI and Trade in Portugal: a gravity analysis. Research Work in Progress. №174. P. 1-24.

AZEEM, S., HUSSAIN, H., HUSSAIN, R. (2012). The determinants of foreign investment in Pakistan: a gravity model analysis. Log Forum. Scientific Journal of Logistics. 8 (2). P. 81-97.

BALDWIN, R., DI NINO, V. (2006). Euros and Zeros: The Common Currency Effect on Trade in New Goods. NBER Working Paper 12673.

BATTERSBY, B., EWING, R. (2005). International trade performance: The gravity of Australia's remoteness. Treasury Working Paper, 2005-03.

BÉNASSY-QUÉRÉ, A., COUPET, M., MAYER, T. (2005). Institutional Determinants of Foreign Direct Investment. CEPII Working Paper No. 2005-05. Paris: CEPII research center. P. 1-30.

BEVAN, A., ESTRIN, S. (2004). The determinants of foreign direct investment into European transition economics. Journal of Comparative Economics. 32. P. 775-787. DOI: $10.1016 /$ j.jce.2004.08.006

BOBONIS, G., SHATZ, H. (2007). Agglomeration, Adjustment, and State Policies in the Location of Foreign Direct Investment in the United States. The Review of Economics and Statistics, 89(1), 30-43.

BORMANN, C., JUNGNICKEL, R., KELLER, D. (2005). What gravity models can tell us about the position of German FDI in Central and Eastern Europe. HWWA discussion paper. P.1-34.

BRAINARD, S. (1997). An Empirical Assessment of the Proximity- Concentration Trade-off Between Multinational Sales and Trade. American Economic Review. 87(4). P. 520-44.

BROADMAN, H., RECANATINI, F. (2001). Where has all the foreign direct investment gone in Russia? Policy Research Working Paper No. 2640, Washington 
D.C., World Bank.

BROCK, G. (1998). Foreign direct investment in Russia's regions 1993-95. Why so little and where has it gone? Economics of Transition 6 (2), 349-360. DOI: 10.1111/j.1468-0351.1998.tb00053.X

BUCCELLATO, T., SANTANGELO, F. (2009). Foreign direct investments distribution in the Russian Federation: Do spatial effects matter? Economics working paper No. 99, Centre for the Study of Economic and Social Change in Europe (CSESCE).

CASTIGLIONE, C., GORBUNOVA, Y., INFANTE, D., SMIRNOVA, J. (2012). FDI determinants in an idiosyncratic country. A reappraisal over the Russian regions during transition years. Communist and Post-Communist Studies, 45, 1-10. DOI: $\underline{10.1016 / j . p o s t c o m s t u d .2012 .02 .006}$

ÇEVIS, I., ÇAMURDAN, B. (2007). The Economic Determinants of Foreign Direct Investment in Developing Countries and Transition Economies. The Pakistan Development Review. 46(3). P.13-47.

CHENG, I-H., WALL, H.J.. (2005). Controlling for heterogeneity in gravity models of trade and integration. Federal Reserve Bank of St. Louis Review, 87, 1, 49-63.

COE, D., SUBRAMANIAN, A., TAMIRISA, N., BHAVNANI, R. (2002). The Missing Globalization Puzzle. IMF Working Paper 02/171, 1-30.

EGGER, P., 2002. An Econometric View of the Estimation of Gravity Models and the Calculation of Trade Potentials. World Economy 25(2), 297-312. DOI: 10.1111/1467$\underline{9701.00432}$

EGGER, P., PFAFFERMAYR, M. (2004). Distance, trade and FDI: a SUR HausmanTaylor approach. Journal of Applied Econometrics. 19(2). P. 227-246. DOI: $10.1002 /$ jae. 721

FRANCOIS, J., MANCHIN, M. (2013). Institutions, Infrastructure, and Trade. World Development, 46, 165-175. DOI: 10.1016/j.worlddev.2013.02.009

FOLFAS, P. (2011). FDI between EU member states: gravity model and taxes. Working paper.

GROSSMAN, G., HELPMAN, E., SZEIDL, A. (2006). Optimal integration strategies for the multinational firm. Journal of international economics. 70 (1). P. 216-238. DOI: 10.1016/j.jinteco.2005.07.011

FUJITA, M. (2005). Expert Meeting on Capacity Building in the Area of FDI: Data Compilation and Policy Formulation in Developing Countries. DITE/UNCTAD. 21p.

HATTARI, R., RAJAN, R. (2009). What explains intra-Asian FDI flows: do distance and trade matter? Economic Bulletin. 29. P. 122-128.

HELPMAN, E. (1984). A Simple Theory of International Trade with Multinational Corporations. Journal of Political Economy. 92 (3). P. 451-471. DOI: 10.1086/261236 
HELPMAN, E., KRUGMAN, P. (1985). Market Structure and Foreign Trade. Cambridge. MA. P. 342-376.

HELPMAN, E., MELITZ, M., RUBINSTEIN, Y. (2008). Estimating trade flows: Trading partners and trading volumes. Quarterly Journal of Economics. 123. P. 441487. DOI: $10.1162 /$ qjec.2008.123.2.441

HELPMAN, E., MELITZ, M., YEAPLE, S. (2004). Export Versus FDI with Heterogeneous Firms. American Economic Review. 94(1). P. 300-316. DOI: $\underline{10.1257 / 000282804322970814}$

IWASAKI, I., SUGANAMA, K.. (2005). Regional distribution of foreign direct investment in Russia. Post-Communist Economies 17 (2). P. 153-172. DOI: $\underline{10.1080 / 14631370500104828}$

KAYAM, S., M. HISARCIKLILAR. (2009). Revisiting the investment developing path (IDP): a nonlinear fluctuation approach. International Journal of Applied Econometrics and Quantitative Studies 6 (2). P. 63-82.

KLEINERT, J., F. TOUBAL. (2010). Gravity for FDI. Review of International Economics. 18(1). P. 1-13. DOI: 10.1111/j.1467-9396.2009.00869.X

KRISTJANSDOTTIR, H. (2004). Determinants of Exports and Foreign Direct Investment in a Small Open Economy. Ph. D. Dissertation. University of Iceland. Faculty of Business and Economics.

LEDYAEVA, S. (2007). Spatial econometric analysis of determinants and strategies of FDI in Russian regions in pre- and post-1998 financial crisis periods. BOFIT discussion papers, Bank of Finland, Institute for Economies of Transition.

LEDYAEVA, S., LINDEN, M. (2006). Testing for Foreign Direct Investment gravity model for Russian regions. Department of Business and Economics. University of Joensuu. Working paper No.32.

LEIBRECHT, M., RIEDL, A. (2012). Modeling FDI based on a spatially augmented gravity model: Evidence for Central and Eastern European Countries. Working Paper Series in Economics. 239.

MANAENKOV, D. (2000). What determines the region of location of an FDI project? An empirical assessment. Working Paper BSP/00/036R, Moscow: New Economic School.

MARKUSEN, J. (1984). Multinationals, multi-plant economies, and the gains from trade. Journal of International Economics. Vol. 16. P. 341-356. DOI: 10.1016/S00221996(84)80001-X

MARKUSEN, J. (2002). Multinational Firms and the Theory of International Trade. Cambridge. MA: MIT Press.

MARKUSEN, J., VENABLES, A. (1998). Multinational firms and the new trade theory. Journal of International Economics. 46. P. 183-203. DOI: 10.1016/S00221996(97)00052-4 
MARTIN, W., PHAM, C. (2008). Estimating the gravity equation when zero trade flows are frequent. Technical report.

MÀTYÀS, L. (1998). The Gravity Model: Some Econometric Considerations. The World Economy. 21. P. 397-401. DOI: 10.1111/1467-9701.00136

McKinsey Global Institute. (2003). Offshoring: Is it a win-win game? San Francisco: McKinsey.

MUNDELL, R. (1957). International Trade and Factor Mobility. American Economic Review. 47. P. 17-29.

PAGANO, M., VOLPIN, P. (2005). Managers, Workers and Corporate Control. Journal of Finance. 60 (2). P. 841-68. DOI: 10.1111/j.1540-6261.2005.00748.x

PANIAGUA, J. (2011). FDI Gravity Equation: Models, Estimations and Zeros. Catholic University of Valencia. Working Paper.

SHEPOTYLO, O. (2009). Gravity with Zeros: Estimating Trade Potential of CIS Countries. Working Paper.

SILVA, S., TENREYRO, J. (2006). The log of gravity. The Review of Economics and Statistics. 2006. 88(4). P. 641-658.

SOVA, R., ALBU, L., STANCU, I., SOVA, A. (2009). Patterns of foreign direct investment in the new EU countries. Romanian Journal of Economic Forecasting. 6. P. 42-51.

TALAMO, G. (2003). Institution, FDI and the Gravity Model. University of Palermo, Department of Political Studies. Working Paper.

TINBERGEN, J. (1962). An Analysis of World Trade Flows. Shaping the World Economy. New York. NY: Twentieth Century Fund.

TALAMO, G. (2013). Institution, FDI and the Gravity Model. Preliminary version. P. $1-24$.

WANG, Z., WINTERS, L. (1991). The Trading Potential of Eastern Europe. CEPR Discussion Paper no. 610. London, Centre for Economic Policy Research.

WEI, Sh-J. (1996). Intra-national versus international trade: how stubborn are nations in global integration? NBER Working paper 5531.

WORLD INVESTMENT REPORT. (2011). Non-equity modes of international production and development. UNCTAD.

WORLD INVESTMENT REPORT. (2014). Investing in the SDGs: an action plan. UNCTAD.

YUKHANAEV, A., SHARMA S., NEVIDIMOVA A. (2014). Subnational determinants of foreign direct investments in the Russian Federation. Journal of Eastern European and Central Asian Research Vol. 1, No. 2. P. 1-10. DOI: $\underline{10.15549 / \text { jeecar.v1i2.62 }}$ 


\section{Appendix}

Table 7 Basic methods of gravity model testing

\begin{tabular}{|c|c|c|c|}
\hline Method & Advantages & Disadvantages & Papers \\
\hline OLS & $\begin{array}{l}\text { Easily implemented standard } \\
\text { method }\end{array}$ & $\begin{array}{l}\text { Elimination of zero and } \\
\text { negative flows } \\
\text { Biased estimators }\end{array}$ & $\begin{array}{l}\text { Africano (2005); } \\
\text { Hattari, Rajan (2009); } \\
\text { Ledyaeva, Linden } \\
\text { (2006); Paniagua } \\
\text { (2011) }\end{array}$ \\
\hline OLS (FDI+const) & $\begin{array}{l}\text { Easily implemented standard } \\
\text { method } \\
\text { Problem with zero flows } \\
\text { solved }\end{array}$ & Biased estimators & $\begin{array}{l}\text { Bénassy-Quéré, } \\
\text { Coupet, Mayer (2005) }\end{array}$ \\
\hline Tobit & $\begin{array}{l}\text { Problem with zero flows } \\
\text { solved }\end{array}$ & $\begin{array}{l}\text { Lack of theoretical } \\
\text { base } \\
\text { The same variables for } \\
\text { censoring probability } \\
\text { and dependent variable } \\
\text { value }\end{array}$ & $\begin{array}{l}\text { Martin and Pham } \\
(2008) ; \text { Hattari, Rajan } \\
(2009)\end{array}$ \\
\hline Panel data with FE & $\begin{array}{l}\text { Easily implemented } \\
\text { Controls for unobserved } \\
\text { heterogeneity }\end{array}$ & $\begin{array}{l}\text { Loss of information } \\
\text { (elimination of } \\
\text { important fixed } \\
\text { variables) } \\
\text { Elimination of zero } \\
\text { flows }\end{array}$ & $\begin{array}{l}\text { Egger and } \\
\text { Pfaffermayr (2003); } \\
\text { Kristjansdottir } \\
\text { (2005); Azeem, } \\
\text { Hussain and Hussain } \\
\text { (2012); Sova } \text { et al. } \\
(2009)\end{array}$ \\
\hline $\begin{array}{l}\text { Panel data with } \\
\text { RE }\end{array}$ & $\begin{array}{l}\text { Solves endogeneity problem } \\
\text { Maintains time invariant } \\
\text { variables }\end{array}$ & $\begin{array}{l}\text { Individual effects } \\
\text { correlate with some } \\
\text { explanatory variables }\end{array}$ & $\begin{array}{l}\text { Bevan and Estrin } \\
(2004) ; \text { Azeem, } \\
\text { Hussain and Hussain } \\
(2012) ; \text { Sova } \text { et al. } \\
(2009)\end{array}$ \\
\hline $\begin{array}{l}\text { Hausman-Taylor } \\
\text { approach }\end{array}$ & $\begin{array}{l}\text { Maintains fixed variables in } \\
\text { regression and allows } \\
\text { correlation between fixed } \\
\text { effects and regressors } \\
\text { Unbiased estimators }\end{array}$ & Hard to implement & $\begin{array}{l}\text { Egger and } \\
\text { Pfaffermayr (2001); } \\
\text { Folfas (2011) }\end{array}$ \\
\hline $\begin{array}{l}\text { Heckman two-step } \\
\text { procedure }\end{array}$ & $\begin{array}{l}\text { Different variables for } \\
\text { censoring probability and } \\
\text { dependent variable value } \\
\text { No multicollinearity problem } \\
\text { Works with zero flows } \\
\text { problem }\end{array}$ & $\begin{array}{l}\text { Difficulties in finding } \\
\text { the identification } \\
\text { restriction } \\
\text { Excludes variables } \\
\text { requirement }\end{array}$ & $\begin{array}{l}\text { Martin and Pham } \\
\text { (2008); Hattari and } \\
\text { Rajan (2009) }\end{array}$ \\
\hline PPML & $\begin{array}{l}\text { Problem with zero flows } \\
\text { solved } \\
\text { Unbiased estimators in the } \\
\text { presence of } \\
\text { heteroskedasticity } \\
\text { All observations weighted } \\
\text { equally }\end{array}$ & $\begin{array}{l}\text { Iterations processed a } \\
\text { rather long time } \\
\text { In STATA, poisson } \\
\text { and ppml commands } \\
\text { don't allow working } \\
\text { with negative values }\end{array}$ & $\begin{array}{l}\text { Silva and Tenreyro } \\
(2006) ; \text { Kleinert and } \\
\text { Toubal (2010); } \\
\text { Paniagua (2011) }\end{array}$ \\
\hline
\end{tabular}


Table 8 List of countries

\begin{tabular}{|c|c|}
\hline Recipient countries & Investing countries \\
\hline $\begin{array}{l}\text { Austria, Albania, Argentina, Australia, } \\
\text { Belarus, Belgium, Brazil, Bulgaria, } \\
\text { Canada, Croatia, Cyprus, Czech Republic, } \\
\text { Denmark, Estonia, Finland, France, } \\
\text { Georgia, Germany, Greece, Hungary, } \\
\text { Iceland, Indonesia, Ireland, Italy, Japan, } \\
\text { Korea, Latvia, Lithuania, Mexico, } \\
\text { Netherlands, New Zealand, Norway, } \\
\text { Poland, Portugal, Romania, Russia, } \\
\text { Slovakia, Slovenia, Spain, Sweden, } \\
\text { Switzerland, Turkey, United Kingdom, } \\
\text { USA }\end{array}$ & $\begin{array}{l}\text { Australia, Austria, Belgium, Canada, } \\
\text { Chile, Czech Republic, Denmark, Estonia, } \\
\text { Finland, France, Germany, Greece, } \\
\text { Hungary, Iceland, Ireland, Israel, Italy, } \\
\text { Japan, Korea, Luxemburg, Mexico, } \\
\text { Netherlands, New Zealand, Norway, } \\
\text { Poland, Portugal, Slovakia, Spain, } \\
\text { Slovenia, Sweden, Switzerland, Turkey, } \\
\text { United Kingdom, USA, Isle of Man, } \\
\text { Jersey, Liechtenstein, Malta, Romania, } \\
\text { Russia, Ukraine, South Africa, Argentina, } \\
\text { Brazil, Colombia, China, Hong Kong, } \\
\text { India, Indonesia, Kazakhstan, Malaysia, } \\
\text { Mongolia, Myanmar, Nepal, Pakistan, } \\
\text { Philippines, Singapore, Taiwan, Thailand, } \\
\text { Vietnam, Seychelles, Andorra, Panama, } \\
\text { British Virgin Islands, Cote d'Ivoire, } \\
\text { Congo, Gabon, Bahamas, Barbados, } \\
\text { Belize, Bermuda, Cayman, Costa Rica, } \\
\text { Cuba, Guatemala, Nigeria, Senegal, } \\
\text { Bangladesh, Lithuania, Latvia, Belarus, } \\
\text { Bosnia and Herzegovina, Bulgaria, } \\
\text { Croatia, Cyprus, Gibraltar, Algeria, Egypt, } \\
\text { Libya, Morocco, Tunisia, Mauritius, } \\
\text { Liberia, Angola, Paraguay, Peru, Uruguay, } \\
\text { Venezuela, Iran, Bahrain, Iraq, Kuwait, } \\
\text { Oman, Qatar, Saudi Arabia, United Arab } \\
\text { Emirates, Yemen, Cameroon, Armenia, } \\
\text { Azerbaijan, Lebanon, Jersey }\end{array}$ \\
\hline
\end{tabular}

